\title{
Morphological description and ecology of some rare macroalgae in south-central Spanish rivers (Castilla-La Mancha Region)
}

\author{
Jose Luis Moreno Alcaraz ${ }^{1 *}$, Laura Monteagudo Canales ${ }^{1} \&$ Marina Aboal Sanjurjo ${ }^{2}$ \\ ${ }^{1}$ Centro Regional de Estudios del Agua, Universidad de Castilla-La Mancha, ctra. de Las Peñas km 3, E-02071 Albacete, Spain \\ ${ }^{2}$ Departamento de Biología Vegetal, Universidad de Murcia, Campus de Espinardo, E-30100 Murcia, Spain \\ joseluis.moreno@uclm.es; laura.monteagudo@uclm.es; maboal@um.es
}

\begin{abstract}
Moreno Alcaraz, J.L., Canales Monteagudo, L. \& Aboal Sanjurjo, M. 2013. Morphological description and ecology of some rare macroalgae in southcentral Spanish rivers (Castilla-La Mancha Region). Anales Jard. Bot. Madrid 70(1): 81-90.

The Castilla-La Mancha Region (south-central Spain) is scarcely studied in terms of freshwater algae. However, both the implementation of the Water Framework Directive (2000/60/CE) and the evaluation of the ecological state of European aquatic ecosystems have increased the intensity and frequency of water body monitoring, including the rivers, lakes and wetlands of this region. Thus, our knowledge on algal biodiversity and the geographical distribution of many species is rapidly increasing. In this study we describe the occurrence, ecological conditions and morphological characteristics of five algal species which are rare at the European level: Nostochopsis lobata Wood ex Bornet \& Flahault, Batrachospermum atrum (Hudson) Harvey, Chroothece richteriana Hansg., Oocardium stratum Nägeli and Tetrasporidium javanicum Möbius. In addition, we include Hydrurus foetidus (Vill.) Trev., a more common alga in Spain, since this is the first record for the region. Finally, we compare morphological and ecological characteristics of the studied populations with other European records.
\end{abstract}

Keywords: Algae, stream, river, Spain, Cyanophyceae, Rodophyceae, Chlorophyceae.

\section{INTRODUCTION}

The Castilla-La Mancha administrative region (south-central Spain) remains as one of the most unknown of the Iberian Peninsula in relation to river algae diversity. Five main river basins are included in this region: Tajo, Júcar, Guadiana, Guadalquivir and Segura, but only the last has been intensely surveyed with regards to algae (e.g. Aboal \& Llimona, 1985; Aboal, 1988a-c, 1989a-c; Sabater \& al., 1989; Aboal \& al., 1996). The rest of region is scarcely studied (e.g. Aboal, 1996; Álvarez \& al., 2007) although a species list of Charophytes in Castilla-La Mancha focusing mainly on wetland areas has been published by Cirujano \& Medina (2002). Additionally, a recent review on the status of river aquatic plants in this region (Moreno \& al., 2011) provides an up to date regional catalogue of aquatic bryophyte species as well as a list of macroalgae genera.

The implementation of the Water Framework Directive (2000/60/CE) and the evaluation of the ecological state of European aquatic ecosystems have increased the intensity and frequency of monitoring of water bodies, including the rivers, lakes and wetlands of the study area. The assessment of the ecological state of rivers by applying the Water Framework Directive (WFD) implies the monitoring of the biological element

\section{Resumen}

Moreno Alcaraz, J.L., Canales Monteagudo, L. \& Aboal Sanjurjo, M. 2013. Descripción morfológica y ecología de algunas macroalgas fluviales de la España centromeridional (Castilla-La Mancha). Anales Jard. Bot. Madrid 70(1): $81-90$ (en inglés).

El conocimiento sobre la biodiversidad algal de la región de Castilla-La Mancha, situada en la zona centro-sur de España, es escaso en comparación con el de otras regiones peninsulares. Sin embargo, la aplicación de la Directiva Marco del Agua (2000/60/CE), y la evaluación del estado ecológico de los ecosistemas acuáticos europeos, ha traído consigo un aumento en la frecuencia e intensidad en el muestreo de ríos, lagos y humedales. De esta forma, durante los últimos años se han producido nuevos hallazgos en la región que han permitido ampliar el conocimiento de la biodiversidad de algas así como de la distribución geográfica de muchas de sus especies. En este trabajo se describen las condiciones ecológicas y las características morfológicas de cinco especies que pueden considerarse raras a nivel europeo: Nostochopsis lobata Wood \& Bornet \& Flahault, Batrachospermum atrum (Hudson) Harvey, Chroothece richteriana Hansg., Oocardium stratum Nägeli y Tetrasporidium javanicum Möbius; y de una sexta especie, frecuente en España y Europa, pero que supone la primera cita para esta región, Hydrurus foetidus (Vill.) Trev. Finalmente, se comparan las características morfológicas y ecológicas de las poblaciones estudiadas con otras citas Europeas.

Keywords: Algae, arroyo, río, España, Cyanophyceae, Rodophyceae, Chlorophyceae.

"macrophytes and phytobenthos". As a consequence, knowledge on macroalgal biodiversity and the geographical distribution of many species has rapidly increased in recent years.

In this study we describe the occurrence, ecological conditions and morphological characteristics of some uncommon algal taxa. One of them has been the first record for Spain and the third for Europe: Nostochopsis lobata Wood ex Bornet \& Flahault; four additional species are hardly cited in Europe: Batrachospermum atrum (Hudson) Harvey, Chroothece richteriana Hansg., Oocardium stratum Nägeli and Tetrasporidium javanicum Möbius; and finally, Hydrurus foetidus (Vill.) Trev., which has been collected in cold streams of some mountains of Spain although our record is the first cite for the study area.

All the taxa were found within the boundaries of the Autonomous Community of Castilla-La Mancha (south-central Spain) (Fig. 1) which occupies an area of $79409 \mathrm{~km}^{2}$. This region includes the upper and middle reaches of five large river basins: Tajo, Guadiana, Guadalquivir, Júcar and Segura. Land uses are mainly agriculture ( $46 \%$ of the regional area) and forest (44\%). Regarding geology, three zones can be distinguished: the western zone is rich in Precambrian siliceous rocks (mostly quartzite, slate, shale, granite and gneiss); Meso-

\footnotetext{
* Corresponding author.
} 


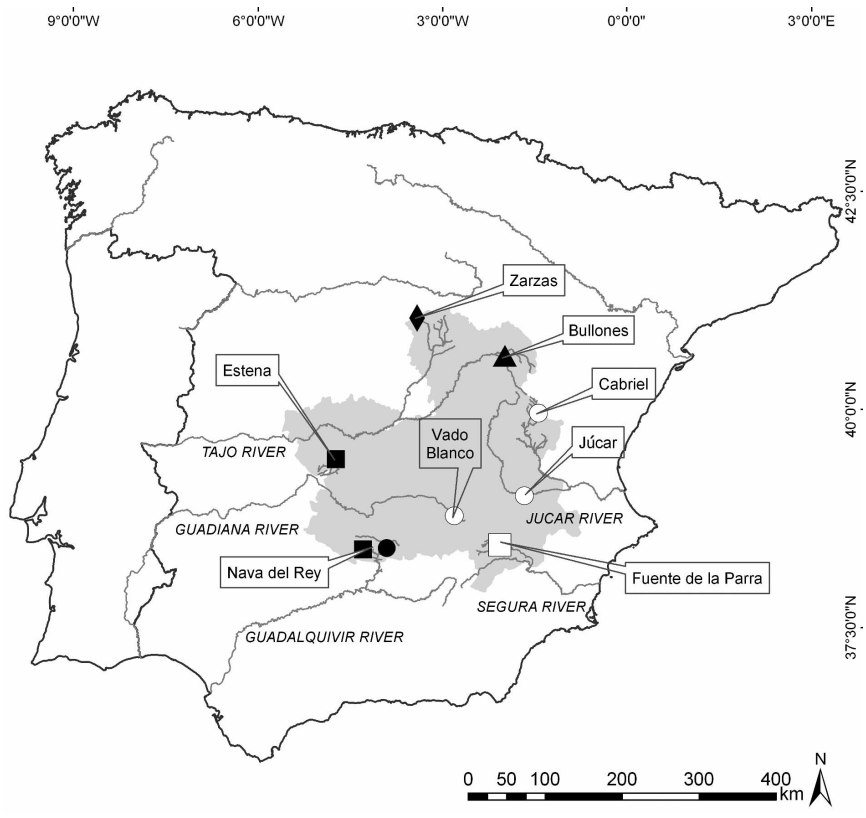

Fig. 1. Map of the Iberian Peninsula showing the limits of the Castilla-La Mancha Region, the main rivers crossing the study area and the location of the species recorded. Hydrurus foetidus; $\square$ Oocardium stratum; Nostochopsis lobata; $\boldsymbol{\Delta}$ Chroothece richteriana; $\bigcirc$ Batrachospermum atrum; - Tetrasporidium javanicum; $\square$ Castilla-La Mancha Region.

zoic calcareous rocks (limestone, dolomite, sandstone and conglomerates) are dominant in the eastern area; and finally, Tertiary sedimentary fills are accumulated in the great central plateau located at $700 \mathrm{~m}$ a.s.l. called "La Mancha", where clays, sandstones, gravels, stones, conglomerates, marls and gypsum are predominant (González \& Vázquez, 2000). Mountains are located mainly on the edges of the region and can reach more than $2000 \mathrm{~m}$ (2273 m, Pico del Lobo)

\section{MATERIAL AND METHODS}

As part of a regional river monitoring program, a stream reach of approximately $100 \mathrm{~m}$ long was deeply surveyed for macroalgae, including all microhabitats present, e.g. riffles, pools, runs or stream margins as well as different kinds of substrata (sand, gravel, stones, aquatic vegetation, etc.). Macroalgal samples were collected in the river by hand and taken to the laboratory. One part of the samples was fixed in $3 \%$ formaldehyde in the field whereas the other part was maintained fresh until laboratory observations. Collected material was examined under a Leica M165C stereoscope and a light microscope OLYMPUS BX50. Glycerin-gelatine was used to make permanent slides which were used to take cell measurements. Drawings were made with the help of macroscopic and microscopic images taken by a Leica DFC $420 \mathrm{C}$ camera and also by direct observation of samples. Electric conductivity, $\mathrm{pH}$ and dissolved oxygen were measured in situ using appropriate sensors (Multiline P4 WTW). Alkalinity was also obtained in the field using the sulphuric acid method (APHA, 1998). In addition, water samples were collected in polyethylene bottles (500 $\mathrm{ml}$ ) and were kept in the refrigerator at $4{ }^{\circ} \mathrm{C}$. All physico-chemical parameters were analyzed within $48 \mathrm{~h}$ after sampling. The concentration of nutrients $\left(\mathrm{N}^{-\mathrm{NO}_{3}}{ }^{-}, \mathrm{N}_{-} \mathrm{NO}_{2}, \mathrm{~N}_{-} \mathrm{NH}_{4}^{+}\right.$, and $\mathrm{P}-$ $\mathrm{PO}_{4}^{-3}$ ) was determined photometrically with MERCK Kits (Spectroquant ${ }^{\mathbb{1}}$ ); ion chromatography was used to analyse chloride and sulphate; turbidity with a turbidimeter TN-100 (Eutech Instruments; infrared light); calcium and magnesium by complexometry (volumetry); sodium and potassium by atomic emission. All these parameters were analysed following standard procedures detailed in APHA (1998).

\section{RESULTS}

Nostochopsis lobata Wood ex Bornet \& Flahault (Fig. 2a-c)

Some specimens of $N$. lobata were found at the Nava del Rey stream (Fig.1), a temperate temporary stream tributary of the Guadalquivir river. The stream was located in the southern part of Castilla-La Mancha (Province of Ciudad Real), and it flows over Palaeozoic siliceous metamorphic rocks (quartzites, slates and shales). The study site was located at medium altitude (590 m) at $9.5 \mathrm{~km}$ from the source with an upstream drainage area of $41.76 \mathrm{~km}^{2} . N$. lobata was found when the stream was at base flow condition (June 2009). Two morphological forms were collected: compact globular specimens corresponding to young colonies (Fig. 2a,b) were found attached to a moss stem whereas free floating diffluent fragments coming from senescent colonies were collected entangled with other macrophytes. Young colonies measured $0.5-3 \mathrm{~cm}$ in diameter while diffluent fragments were about $0.1-1 \mathrm{~cm}$; and its colour changed from brownish to bluish, respectively. The radial disposition of filaments could be clearly observed in the outer part of the colonies, in transversal sections (Fig. 2b). Cells were isodiametrical to cylindrical, measuring from $2.0 \mu \mathrm{m}$ up to $6.17 \mu \mathrm{m}$ in diameter and length up to $7 \mu \mathrm{m}$. Heterocytes were predominantly lateral, sessile or pedicellate (Fig. 2c), measuring from $6.7 \mu \mathrm{m}$ to $8.0 \mu \mathrm{m}$ in diameter. Intercalary heterocytes were rare. The waters were oligo-mesotrophic, with low conductivity and alkalinity values (Table 1). The specimens were collected at marginal depositional habitats along with other aquatic macroflora such as Ranunculus peltatus Schrank, Cladophora sp., Spirogyra sp., Oedogonium sp., Zygnema sp. and Tetrasporidium sp.

\section{Batrachospermum atrum (Hudson) Harvey (Fig. 2d-f)}

B. atrum was found at three study sites: the Vado Blanco stream, Cabriel stream and Júcar river (Fig. 1). The Vado Blanco stream connects two lagoons of the Ruidera lagoon complex made up of 15 karstic lagoons located on a high altitude calcareous plateau (around $900 \mathrm{~m}$ a.s.1.) where forest and irrigation land are the main land uses. Nitrate concentration in groundwater and surface water is high due to intensive agriculture practises developed in the last decades (Berzas \& al., 2004). The Cabriel Stream is the main tributary of the Júcar River and the study site was located at a high altitude near its source (1156 m a.s.l.) in a mountainous area where forest is predominant. Groundwater inputs from springs and upwellings are important in this stream reach. The last study site was located in a middle reach of the River Júcar at medium altitude $(600 \mathrm{~m})$ in a wide valley dedicated to agricultural uses. The influence of a reservoir located $96.65 \mathrm{~km}$ upstream is very signi- 


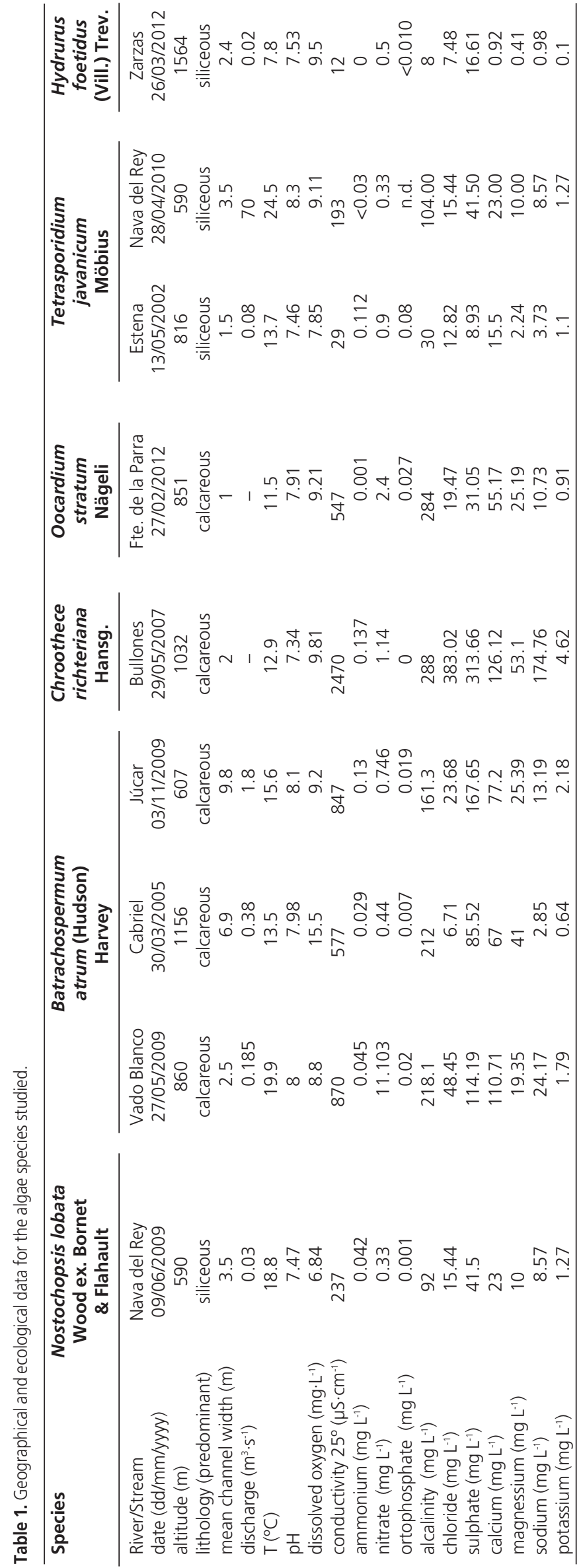

ficant due to flow regulation for agriculture. The river reach is also influenced by groundwater upwelling and seepages that contribute to feed the river. The specimens were collected submerged in the stream margins, mainly over other macroalgae or entangled with them and exposed to a low current velocity. Thallus size ranged from $2.5-8 \mathrm{~cm}$ long and $60-120 \mu \mathrm{m}$ wide, colour red-brownish, without mucilage (Fig. $2 \mathrm{~d}$ and 2e), showing a regular cortication (Fig. 2f) along its central axis and branches. The mean distance between nodes was of 250-525 $\mu \mathrm{m}$ and decreasing from the central axis base towards the apical branches (up to $80 \mu \mathrm{m}$ in branch tips). The whorls were very reduced, 100-200 $\mu \mathrm{m}$ diameter, non-adherent to the main axis, and ring or pearl shaped (obconical). Primary fascicles were composed of 3-6 barrel-shaped cells of 3.3-6.8 $\mu \mathrm{m}$ in diameter. Secondary fascicles were composed of 1-3 cells, abundant and scattered along the internodes or concentrated in nodes, the apical cell of fascicles usually sharp-pointed. Gonimoblasts were hemispherical, $135-220 \mu \mathrm{m}$ in diameter and 27-80 $\mu \mathrm{m}$ high, attached to the axis in internodes or nodes. Tricogyns shape was clavate, 9.3-16.2 $\mu \mathrm{m}$ long and 6.2-8.3 $\mu \mathrm{m}$ wide, located mainly in internodes but also in nodes and axillas at the base of branches. Tricogyns usually included 1-2 round spermatia of 4.7-6 $\mu \mathrm{m}$ diameter attached to the tip. Regarding environmental conditions, it is important to highlight that the three localities were under groundwater influence. Dissolved nutrients showed low values except for one site (Vado Blanco stream, Lagunas del Ruidera) located at an irrigation area with high levels of nitrate contents (Table 1). Accompanying aquatic macroflora included Anabaena sp., Batrachospermum gelatinosum (L.), Chara aspera C.L. Dethard. ex Willd. and Chara hispida L. in Vado Blanco stream; Apium nodiflorum (L.) Lag., B. gelatinosum and Bryum sp. in Júcar river; and Apium nodiflorum, Audouinella sp. and B. gelatinosum in Cabriel stream.

\section{Chroothece richteriana Hansg (Fig. 3a-c)}

C. richteriana was found in Bullones stream (Fig. 1), a headwater tributary of the River Tajo situated in a calcareous landscape in contact with marls and limestones. The drainage area of subcatchment was $137.97 \mathrm{~km}^{2}$, with $30 \%$ of the area occupied by agriculture and $70 \%$ by natural vegetation. The immediate vicinity of the site was a semi-natural area mainly occupied by Juniperus communis L. and J. thurifera $\mathrm{L}$. The site was located at $1032 \mathrm{~m}$ a.s.1., $25 \mathrm{~km}$ downstream from the source. In general, colonies of this species were bright green, gelatinous and hemispheric in shape. Transversal sections revealed a stratified structure of the hemispherical colony (Fig. 3a): the surface was conformed by a continuous layer of cells on the top of their radially-arranged stalks, with some parallel lines of sediments and carbonate precipitates probably corresponding to growth rings. C. richteriana was found growing epilithic, covering around $80 \%$ of most submerged rocks. Cells were cylindrical and elongated, measuring from $5 \mu \mathrm{m}$ to $9 \mu \mathrm{m}$ in width (6.9 $\mu \mathrm{m}$ average) and from $10 \mu \mathrm{m}$ to $18 \mu \mathrm{m}$ in length $(15.9 \mu \mathrm{m}$ average) (Fig. 3b,c). The cells were surrounded by a thick cell wall (from 2 to $6 \mu \mathrm{m}$ wide) and disposed on the stalks (Fig. 3b). Inside some cells, a star-shaped chromatophore was visible (Fig. 3c). Regarding physico-chemical conditions (Table 1) water was slightly saline due to the presence of marls alterna- 

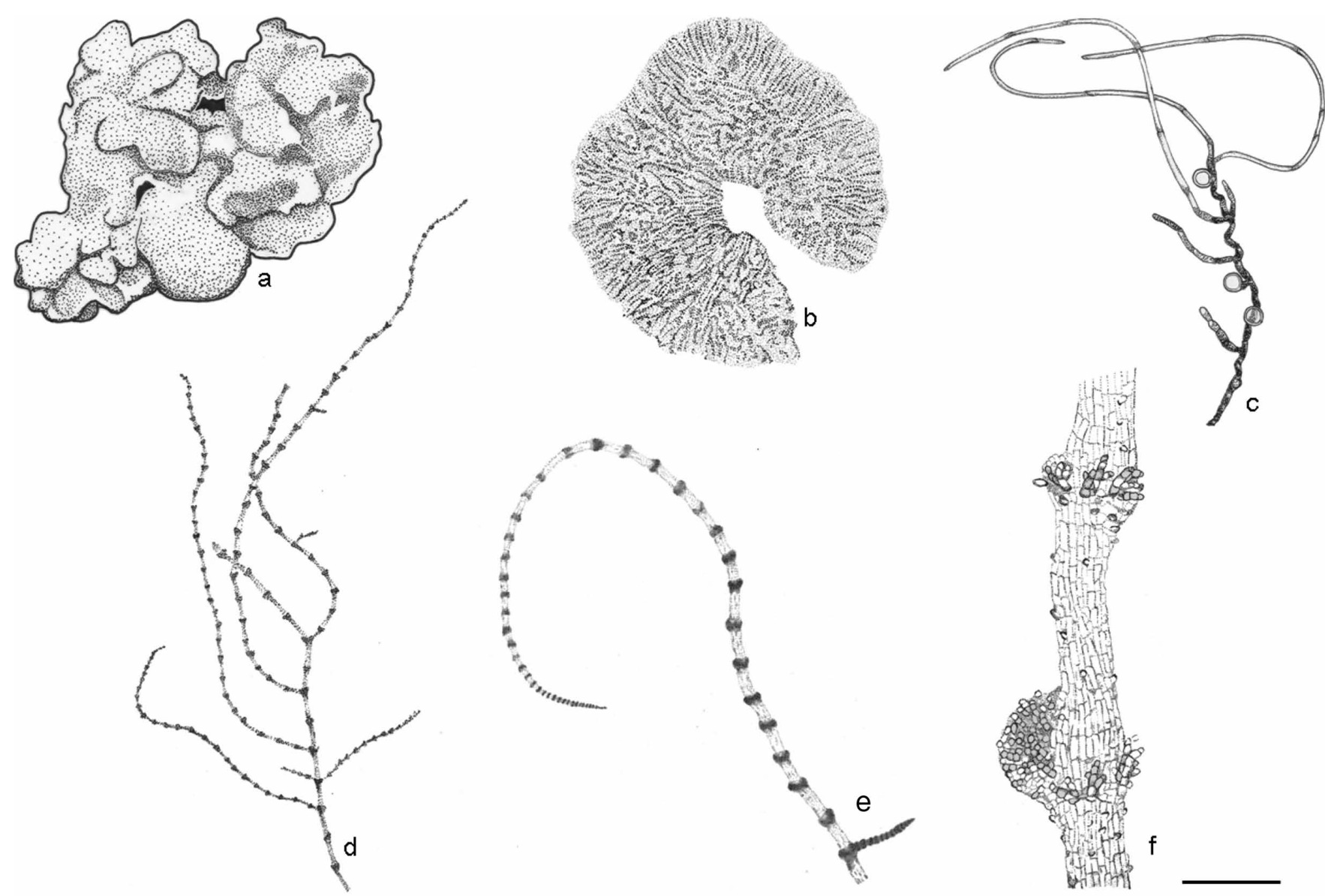

Fig. 2. Nostochopsis lobata: a, macroscopic view; b, transversal section; c, mature filament with heterocytes (from Moreno \& al., in press). Batrachospermum atrum: d, macroscopic view; e, filament; $\mathbf{f}$, detail of gonimoblast and cortication of the thallus. Scale: $a, d=50 \mathrm{~mm} ; b=1 \mathrm{~mm} ; \mathrm{c}, f=50 \mu \mathrm{m}$; $\mathrm{e}=500 \mu \mathrm{m}$.

ting with limestones (I.T.G.E., 2000), with a high content of chloride and sulphate. An industry of salt extraction is located $8 \mathrm{~km}$ upstream (Salinas de Almallá) due to the presence of evaporite outcorps.

Other aquatic taxa detected at the site were: Apium nodiflorum, Veronica anagallis-aquatica L., Chara vulgaris sp., Cladophora sp., Tetraspora sp., Vaucheria sp., Batrachospermum sp., Tolypothrix sp., and Phormidium sp.

\section{Oocardium stratum Nägeli (Fig. 3d-i)}

The desmid zygnematal $O$. stratum was found in Fuente de la Parra stream (Fig. 1), a small tributary of the Mundo River (Segura river basin). This stream runs over calcareous rocks in a mountainous area covered by a Pinus pinaster Ait. forest. The site was located at $851 \mathrm{~m}$ a.s.l. very close to the source $(1.73 \mathrm{~km}$ downstream). The biodiversity and proliferation of macroalgae was low, due to the dense canopy reducing the entry of light. $O$. stratum appeared on mosses, sticks and wet rocks in a small dam $3 \mathrm{~m}$ in height built to retain water from the source, where a travertine formation was extensive across the waterfall. To the naked eye, colonies first formed hemispherical structures like small grains a few millimetres long (Fig. 3d). However, with the growth and the increase of carbonate precipitates, the colonies formed a lobulated layer of calcareous concretions several centimetres thick on twigs and sticks (Fig. 3e). Under the microscope, a lateral vision of a colony (Fig. 3b) showed that this species formed gelatinous branched cylinders surrounded by calcite with bright green cells at the top (Fig. 3g). Cells were heart-shaped, showing a small median constriction as in other desmids such as Cosmarium, and measured around $13.5 \mu \mathrm{m}$ in diameter (11-16 $\mu \mathrm{m})$ (Fig. 3h).

In some cases, colonies of Chroothece rupestris Hangs. were found over colonies of $O$. stratum. After using acetic acid to eliminate carbonate precipitates from Oocardium colonies, filaments of Rivularia sp. were observed inside them (Fig. 3i). These three algae species, together with the moss Didymodon tophaceus (Brid.) Lisa, were revealed to be the main biological builders of the global travertine structure. The accompanying aquatic macroflora included Callitriche stagnalis Scop., Veronica anagallis-aquatica, Chara vulgaris, Batrachospermum gelatinosum, Phormidium sp., Oedogonium sp., Cladophora glomerata (L.) and Microspora sp.

\section{Tetrasporidium javanicum Möbius (Fig. 4a-e)}

In the study area, this clorophyte was found at two sites. The first site was Estena stream (Fig. 1), a small tributary of the Guadiana river running over siliceous rocks. The study site was located in a mountainous area of the Cabañeros National Park, 

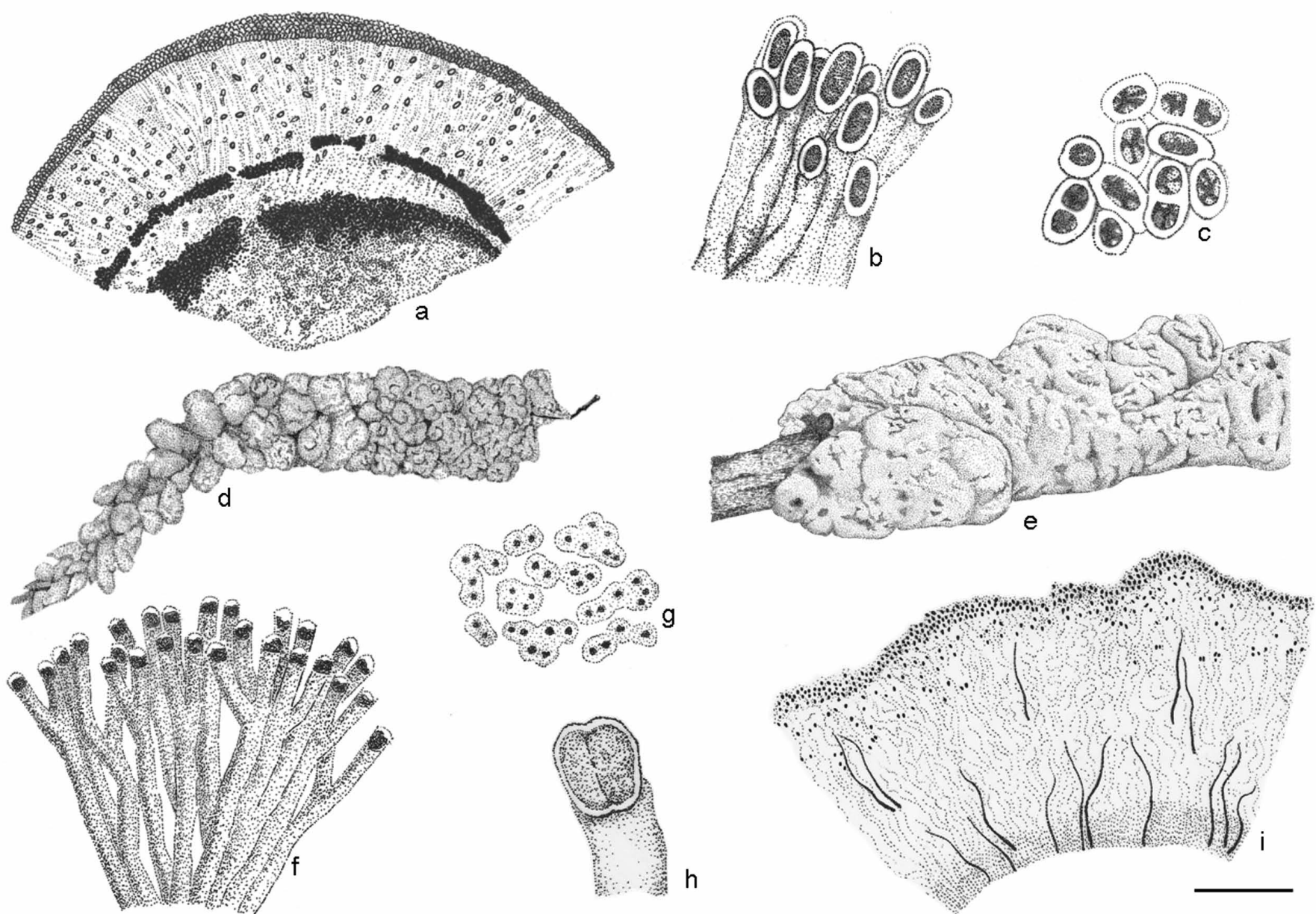

Fig. 3. Chroothece richteriana: a, transversal section of a colony; b, lateral view of pedunculated cells; $\mathbf{c}$, cells with star-shaped chromatophores. Oocardium stratum: $\mathbf{d}$, small colonies covering a moss branch; e, aged colony forming a thick lobulated layer; $\mathbf{f}$, lateral microscopic view showing the calcite cylinders surrounding cell stalks; $\mathbf{g}$, upper view of cells surrounded by calcite; $\mathbf{h}$, detail of cell with stalk; $\mathbf{i}$, colony of $O$. stratum together with Rivularia after carbonate removal. Scale: $a, i=500 \mu \mathrm{m} ; b, c, h=20 \mu \mathrm{m} ; d=5 \mathrm{~mm} ; e=1 \mathrm{~cm} ; f=100 \mu \mathrm{m} ; \mathrm{g}=200 \mu \mathrm{m}$.

and $6.1 \mathrm{~km}$ downstream from the source. The drainage area was covered by a near natural forest of Quercus Mediterranan maquia. T. javanicum appeared as small (environ $8 \mathrm{~mm}$ in length) free floating colonies forming a light green gelatinous tubular-net thallus (Fig. 4a). These small colonies probably corresponded to fragments of a bigger colony. The 'ribbons' making up the thallus (Fig. $4 \mathrm{~b}$ ) measured 100-300 $\mu \mathrm{m}$ wide and presented revoluted margins. Cells were heterogeneously arranged in the mucilage and were spherical to slightly oval in shape (Fig. 4c). A wide range of cell size was observed: from 5.1-10.7 $\mu \mathrm{m}$ in diameter, with $8.2 \mu \mathrm{m}$ on average. Chloroplasts were parietal with a single large pyrenoid (around $1.6 \mu \mathrm{m}$ in diameter). Pseudo-flagella, typical of the genus Tetraspora, were absent. Environmental and physico-chemical data recorded for this site indicated that the stream was mesotrophic, showing a very low mineralisation due to the siliceous lithology (Table 1). The waters showed a carbonated character but with a high proportion of chloride. Accompanying aquatic macroflora included Audouinella sp., Draparnaldia sp., Zygnema sp., Tolypothrix sp., Scytonema sp., Nostoc sp., and Chiloscyphus polyantos (L.) Corda.

In addition, we collected Tetrasporidium in another siliceous oligo-mesotrophic stream, the Nava del Rey stream (described in Nostochopsis lobata section), but different morphological characteristics were observed. In this case, colonies were thin perforated sheets (Fig. 4d), the biggest one measuring $1.5 \times 2.1 \mathrm{~cm}$. Cells were smaller and surrounded by concentric gelatinous sheaths (Fig. 4e). The smaller cell size (from $3.3 \mu \mathrm{m}$ to $5.7 \mu \mathrm{m}$ in diameter) of this specimen matched with the description of $T$. fottii Coute et Traccana included in the key of Ettl \& Gärtner (2009), although for other authors Tetrasporidium is a monospecific genus (see discussion).

\section{Hydrurus foetidus (Vill.) Trev. (Fig. 4f-h)}

H. foetidus was found at Zarzas stream (Fig. 1), a headwater tributary of the Hoz stream which belongs to the largest Spanish river basin, the Tajo river. The Zarzas stream runs through the Natural Park of Sierra Norte of Guadalajara, located in the northernmost part of the region. This area is mountainous and is covered by a forest of Pinus sylvestris $\mathrm{L}$. with the presence of Fagus sylvatica L. The study site was located at an altitude of $1564 \mathrm{~m}$, in one of the coldest areas of the region, $7.90 \mathrm{~km}$ downstream from its source. The drainage area of subcatchment is $26.90 \mathrm{~km}^{2}$. This alga was found as gold-brown tufts up to $20 \mathrm{~cm}$ long attached to boulders and stones (Fig. 4f,g) some- 


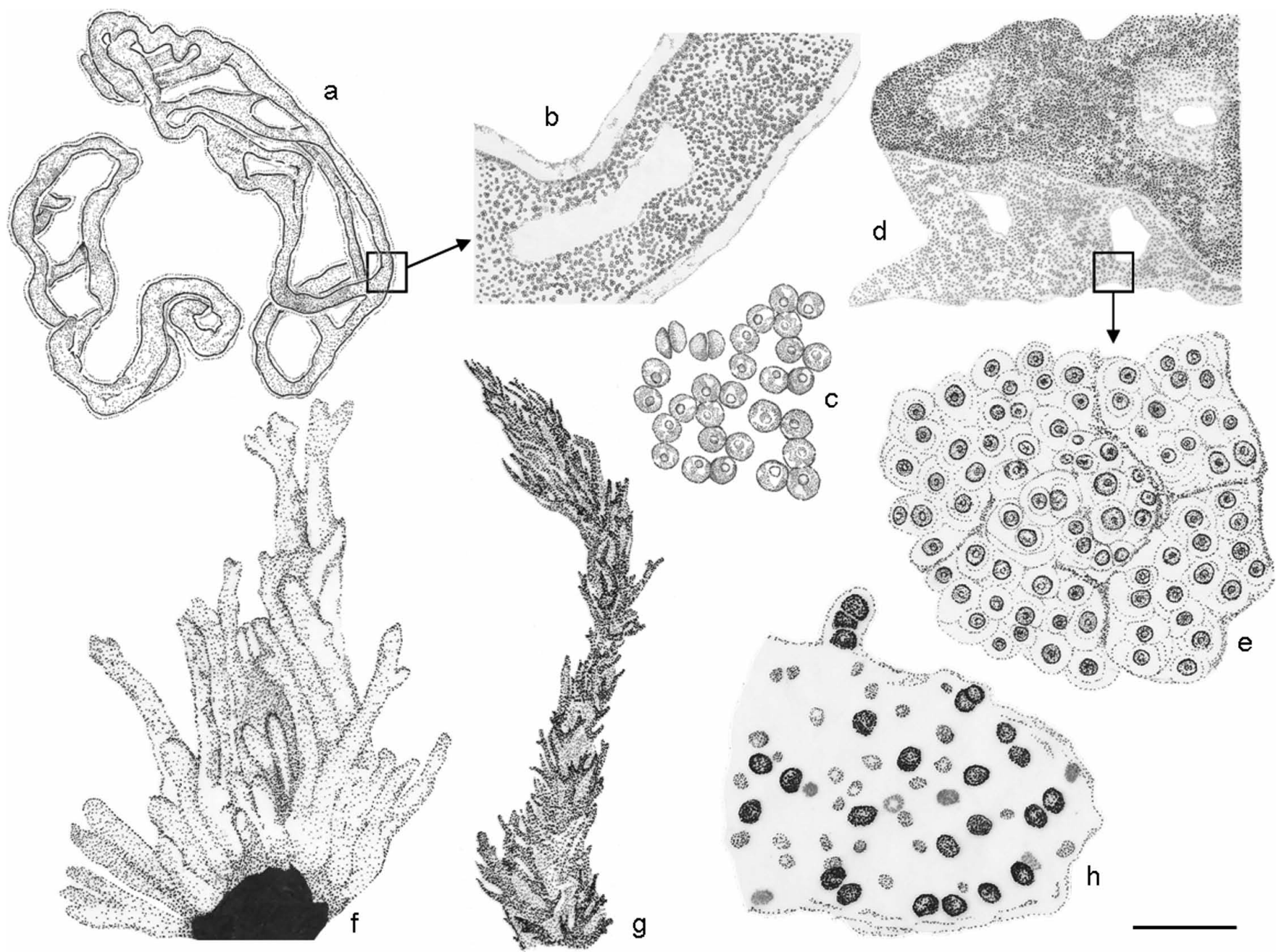

Fig. 4. Tetrasporidium javanicum: a, macroscopic view of a tubular-net colony ("ribbon-like"); $\mathbf{b}$, detail of a part of the colony; $\mathbf{c}$, detail of cells; $\mathbf{d}$, macroscopic view of a laminar colony; e, detail of the colony showing cells surrounded by gelatinous sheaths. Hydrurus foetidus: $\mathbf{f}, \mathbf{g}$, macroscopic view of two thallus shapes; $\mathbf{h}$, detail of cell arrangement within the mucilage. Scales: $a=2 \mathrm{~mm} ; b=100 \mu \mathrm{m} ; c, h=20 \mu \mathrm{m} ; d=500 \mu \mathrm{m} ; \mathrm{e}=50 \mu \mathrm{m} ; \mathrm{f}, \mathrm{g}=1 \mathrm{~mm}$.

times covering $100 \%$ of the substratum. Thalli were branched and gelatinous. Cells embedded in the mucilage were peripherally arranged and oval to ellipsoidal in shape (Fig. 4h). Cell size was 5-8 $\mu \mathrm{m}$ wide $(6.5 \mu \mathrm{m}$ on average) and 7-13.5 $\mu \mathrm{m}$ long $(10.5 \mu \mathrm{m}$ on average $)$ in. Regarding nutrients, waters were oligo-mesotrophic (Table 1). Accompanying aquatic macroflora was made up of the following taxa: Lemanea sp., Hildenbrandria sp., Scapania undulata (Hedw.) P. Beauv., and Marchantia polymorpha $\mathrm{L}$.

\section{DISCUSSION}

N. lobata is included in the family Nostochopsaceae (Anagnostidis \& Komarek, 1990; Komárek \& al., 2003). This species is characterized by a globular lobed thallus composed of uniseriate and branched thricomes with intercalar or lateral heterocytes (pedicellate or sessile) (Bornet \& Flahault, 1886-1888). $N$. lobata is widely distributed in tropical areas of the world and has been reported in several African countries (Frémy, 1929), North and South America and Australia (Cáceres, 1973; Sarma \& Chapman, 1975; Branco \& al., 2001) and Asia (Geitler,
1930-1932; Desikachary, 1959; Tiwari, 1978; Peerapornpisal \& al., 2006). In Europe there are only third records from flowing warm waters: Banyuls-sur-Mer (France) (Frémy \& Feldmann, 1934), Corsica (France) (Hoffmann, 1990), and L'Aquila (Italy) (Del Grosso, 1977). The specimens of N. lobata collected in Nava del Rey were the first recorded in Spain (Moreno \& al., in press). Morphologically, our material matched fairly well the detailed description of the first specimen reported in Europe by Frémy \& Feldmann (1934). In both cases N. lobata was found in small temporary streams running over siliceous metamorphic rocks, located at low altitude and living in warm and oligotrophic waters, and it was collected in summer. In terms of habitat, we found $N$. lobata growing epiphytic (young) and free floating (senescent) even though it has been reported in different habitats: lakes (Tiwari, 1978; El Saied, 2007), running waters (Frémy \& Feldmann, 1934; Palmer, 1941; Pandey \& Pandey, 2008), thermal springs (Yoneda, 1939), epiphytic (Sarma \& Chapman, 1975), attached to rocks (Hoffmann, 1990; Peerapornpisal, 2006), free floating (Wood, 1872), on moist soils (Skinner \& Entwisle, 2001; Aziz, 2008), and on humid walls (Skinner \& Entwisle, 2001) among others. 
However, the most extreme habitat where $N$. lobata has been found is probably as cryptoendolithic in an arid climate (Weber $\&$ al., 1996). Current data point out that this species is distributed worldwide with an underlying tendency: it grows abundantly in tropical regions where its optimal climatic conditions are stable for several months whereas it grows scarcely in other regions only when conditions allowing its germination and growth are reached, probably for a few weeks in occasional years (Moreno \& al., in press). This fact explains the difficulty in detecting this species in Europe, where it has always been recorded only once per site.

$B$. atrum belongs to subgenus Batrachospermum, which is characterized by a carposporophyte multicellular, and to section Setacea which is characterized by short carpogoniumbearing branches and whorls/fascicules (Eloranta \& Kwandrans, 2007). B. atrum (section Setacea) is on divergent branches of molecular trees (Kumano, 2002) and constitutes a distinct section, as proposed by Sheath \& al. (1993). Gonimoblasts form mamilliform or semispherical swellings on the central axis and the trichogyn is clavate; the thallus is subgelatinous (Starmach, 1977). The habitus shows a compressed and compact thallus due to its short fascicules and whorls, resembling a bamboo stem, similar to the thallus of the red algae Lemanea. According to Kumano (2002), B. atrum is distributed throughout Europe (UK, France, Belgium, Germany, Poland, Portugal and Sweden), Eastern Asia (China, Korea and Japan), Australia, New Zealand, South America (Brazil) and Africa (Angola), in addition to the USA (California and Texas; Sheath \& al, 1993). In Spain there is only one previous record from the Murcia Region (Aboal \& al., 1995). The morphological characteristics match with other descriptions provided by other authors (Israelson, 1942; Sheath \& al., 1993; Eloranta \& Kwandrans, 2007). B. atrum is an oligotrophic hard water species (Sládecek, 1973; Rott \& al., 1999; Eloranta \& Kwandrans, 1996, 2002). In Spain, Aboal \& al. (1995) found this species in calcareous springs and small streams with environmental conditions similar to those described in this work. The three sites where $B$. atrum was collected were calcareous and they showed groundwater influence associated to upwelling areas, springs or seepages. The trophic conditions in our sites were oligo-mesotrophic, with one site showing a high concentration of dissolved nitrate due to its location within an intensively irrigated cropland area (Álvarez-Cobelas \& al., 2005). According to Eloranta \& Kwandrans (2007) the species grows epiphytic or epilithic, but in our sites it was collected as epiphytic, floating among other macrophytes close to river banks and avoiding high current velocity, more limnephilic than rheophilic. According to Israelson (1942) and Aboal \& al. (1995) the species seem to occur only in spring, but in the study area the species was recorded both in spring and autumn, similar to the seasonal pattern frequently shown by the rest of the Batrachospermaceae in lotic waters (Aboal \& al., 1995). The fact that the species was collected only once per site despite several visits may be due to the rapid development and short life cycle of the species or to the occasional interannual occurrence.

After $C$. richteriana was described by Hansgirg (1884), few publications about this species have been released. $C$. richteriana has been reported in Britain (Sheath \& Sherwood, 2002; Eloranta \& al., 2011) and Spain (Eloranta \& al., 2011). Recent- ly it has been found growing in slightly saline streams of southeastern Spain (Murcia), mostly on subaerial conditions (unpublished data). This rare Rhodophyte included in the Porphyridiaceae family is characterized by mucilaginous colonies conformed by elliptical cells enclosed in a layered gelatinous matrix (Eloranta \& Kwandrans, 2007; Eloranta \& al., 2011). Additionally, a star-shaped chromatophore is clearly visible inside the cells. Starmach (1977) and Eloranta \& al. (2011) consider cell size as a differential characteristic between the two species of Chroothece present in Castilla-La Mancha: C. richteriana measuring 6-10 $\mu \mathrm{m}$ wide and 15-18 $\mu \mathrm{m}$ long; $C$. rupestris measuring 5-7 $\mu \mathrm{m}$ wide and 9-15 $\mu \mathrm{m}$ long. Additionally, Sheath \& Sherwood (2002) reported a cell size for $C$. richteriana of 8-12 $\mu \mathrm{m}$ wide and 10-21 $\mu \mathrm{m}$ long (British Islands). Both studies match with the cell size of our colonies collected in Bullones stream (5-9 $\mu \mathrm{m}$ wide, 10-18 $\mu \mathrm{m}$ long). However, we noticed that according to our observations, the cell size range of a Chroothece population can exceed that one reported from identification keys. On the other hand, the relatively high water salinity of Bullones stream was in accordance with the "more or less saline" environment described for C. richtheria$n a$ in the identification keys (Eloranta \& al., 2011; Starmach, 1977).

Regarding Chroothece populations from Fuente de la Parra (see Oocardium stratum section), they were identified as C. rupestris according to the identification keys criteria: lower cell size, low water mineralisation, and also the environment "wet rocks". In the same way, Margalef (1989) recorded C. rupestris from wet rocks of calcareous springs, described by him as "hygropetric environment", a similar environment to that of Fuente de la Parra stream.

Oocardium is a monospecific genus belonging to the family Desmidiaceae, characterized by being mostly unicellular, either solitary or in colonies, with cells divided into two compartments separated by an isthmus. West (1904) described Oocardium as the most extraordinary of all the genera of Desmids usually occurring in large colonies. According to West (1904) and Bourrelly (1990), the colonies of O. stratum are hemispherical in shape (1-2 $\mathrm{mm}$ in diameter), and are formed by cells standing on more or less parallel, radiating strands of mucus which are encrusted in calcite. During the growing period, calcite crystals are formed by continuous deposition by surrounding cells which, following division, calcify into slightly different directions upwards (Sanders \& Rott, 2009). The colonies detected in Fuente de la Parra stream matched exactly with the above description and appeared jointed, forming a nodular crust covering substrates, similarly to colonies observed by Pentecost (1991). Regarding the environmental conditions, $O$. stratum seems to have very specific requirements: it is only found in waterfalls and springs with calcareous water (Margalef, 1983; Pentecost, 1991) usually being associated to deposits of travertine and tufa (Pentecost, 2001; Sanders \& Rott, 2009; Bellinger \& Sigee, 2010). Because of these environmental restrictions, $O$. stratum is often considered as an unusual alga (e.g. Margalef, 1983; Bellinger \& Sigee, 2010) even though its presence has been detected worldwide: Switzerland (Nägeli, 1849) the United States of America (Prescott, 1981), Austria (Sanders \& Rott, 2009), United Kingdom (West, 1904; Pentecost, 1991), Ireland (Carter, 1923), 
Belgium (van Oye \& Hubert, 1937), France (Kouwets, 1999), Slovenia (Vrhovsek \& al., 2006). Particularly in Spain, O. stratum has been previously reported in Barcelona (Margalef, 1955), Murcia (Aboal, 1991) and in Castilla-La Mancha (Ruidera Lakes) (Álvarez-Cobelas \& al., 2007), although we think that it could be a common species in calcareous mountains and springs.

T. javanicum is a clorophyte classified within the order Tetrasporales, family Palmellopsidaceae (Ettl \& Gärtner, 2009). In the mature state the thallus is a thin, flat, more or less circular sheet with numerous irregular perforations with a smooth or lobed margin (Iyengar, 1932). Nevertheless, the specimen collected in the Estena River was a tubular-net thallus, probably as a result of the increase in the size perforation with age. This fact supports the idea that ribbon-like and sheetlike thallus could represent plants of different ages (Entwisle \& Skinner, 2001). According to Ettl \& Gärtner (2009) cells are oval to spherical in shape ranging from $6 \mu \mathrm{m}$ to $15 \mu \mathrm{m}$ in diameter, slightly larger than our material (from 5.1 to 10.7). Regarding distribution, this species is abundant in tropical areas within India (Iyengar, 1932), China (Hu \& Wei, 2006), Hawaiian Islands (Sherwood, 2004), Java, the United States, Australia and Bangladesh (Entwisle \& Skinner, 2001) being quite common in tropical areas (Entwistle \& Skinner, 2000). In Europe, T. javanicum has been reported in the Czech Republic, France, Portugal and Spain (Fott \& al., 1965; Coute \& Tracanna, 1981; Calado \& Rino, 1992; Aboal \& al., 1994, respectively). In Spain, this species has been found in the Alicante Province (Aboal \& al., 1994), Cáceres Province (Marín-Murcia \& Aboal, 2007), Galicia (López-Rodríguez \& Penalta-Rodríguez, 2007) and, recently, in the Ebro river basin (NE Spain) (Tomás \& al., in press). In almost all cases, the species is found growing in conditions of low current velocity, well oxygenated alkaline waters, high turbidity and nutrient enrichment due to agricultural practises. However, the material described in this work was found in low-mountain clear water streams. These conditions are more similar to those described by Calado \& Rino (1992) and López-Rodríguez \& Penalta-Rodríguez (2007) for specimens collected in Portugal and Galicia, respectively. Despite the fact that the Estena stream is oligotrophic, T. javanicum was found coinciding with a relatively high concentration of nitrogen compounds (nitrite, nitrate and ammonium). This fact could be due to the preference of T. javanicum for eutrophic waters, as suggested by some authors (Aboal \& al., 1994; Marín-Murcia \& Aboal, 2007; Tomás \& al., in press) pointing to this species as a potential good indicator of eutrophy. Our observations lead us to think that $T$. javanicum is more common than reported up to now in Spain and it will be collected more frequently in upcoming river macrophyte surveys.

Regarding T. fottii, the species was described by Couté \& Tracanna (1981) from some specimens found in Breton ponds. However, we were able to find only one other report on this species in literature, made by Neag \& al. (2005) in the "Alexandru Borza" Botanical Garden, Cluj-Napoca, Romania. Ettl \& Gärtner (2009) differenced T. fottii from other Tetrasporidium species according to the lateral position of the pyrenoid and its cell size (from $6.4 \mu \mathrm{m}$ to $9.5 \mu \mathrm{m}$ in diameter). However, the material collected in Nava del Rey was slightly smaller, measuring from $3.3 \mu \mathrm{m}$ to $5.7 \mu \mathrm{m}$ in diameter. Unfortunately, an appropriate observation of the ultrastructure of cells was not possible and, like Entwisle \& Skinner (2001), we could not conclusively identify our material as $T$. fottii. On the other hand, Calado \& Rino (1992) suggest that the specific characteristics of $T$. fottii could be explained by the cytologic variability within Tetrasporidium javanicum and, therefore, T. fottii should not be considered as an independent species. This idea is contemplated by other authors that classify Tetrasporidium as a monospecific genus (e.g. Bourrelly, 1990). Thus, we assigned our material to $T$. javanicum until more studies unraveling the taxonomy of this interesting genus are released.

The chrysophyte Hydrurus foetidus is included in the order Chromulinales, family Hydruraceae. The thallus is gelatinous, branched and attached to substrate reaching up to $30 \mathrm{~cm}$ long. Cells are ellipsoid to subspherical and they are randomly arranged in the mucilage (Rodriguez \& Vergon, 1996). After collecting, it emanates a characteristic smell. This species is a cold water stenotherm also adapted to strong current velocity, being an exclusive inhabitant of cold mountain streams worldwide $\left(2-12^{\circ} \mathrm{C}\right)$ (Hieber \& al., 2001; Wehr \& Sheath, 2003; Krizmanic \& al., 2008). Under optimal conditions, H. foetidus becomes dominant and may entirely cover submerged rocks, making them very slippery. In Europe it is a well-known inhabitant of alpine streams and those draining glaciated landscapes, where it is described as a predominant or very common macroalga by several authors (e.g. Hieber \& al., 2001; Cantonati \& al., 2006; Krizmanic \& al., 2008). In Spain, H. foetidus has been reported in the Pyrenees (NE Spain) (Margalef, 1948; Llimona \& al.,1985), Cantabrian mountains (N Spain) (Margalef, 1950) and Sierra Nevada (Granada, S Spain) (SánchezCastillo, 1984) with this study being the first recordin for the Castilla-La Mancha region. As for habitat conditions, $H$. foetidus is clearly rheophylic and stenothermic, disappearing when water temperature rises above $10^{\circ} \mathrm{C}$ or $15^{\circ} \mathrm{C}$ according to Wehr \& Sheath (2003) and Starmach (1985), respectively. A combination of hydrological factors and light conditions controls the seasonal fluctuations of this macroalga (Cantonati \& al., 2006). In general, this species is commonly found during winter and spring (Hieber \& al., 2001). In Spain, it is a vernal species found occasionally in summer at high altitudes $(>2000 \mathrm{~m})$ (Llimona \& al., 1985). Our material was collected in early spring at a high altitude $(1564 \mathrm{~m})$ when water temperature was $7.8^{\circ} \mathrm{C}$. Both the cellular size (from $7 \mu \mathrm{m}$ to $13.5 \mu \mathrm{m}$ in length) and the thallus length (up to $20 \mathrm{~cm}$ ) of the specimens coincide with previous literature which describes large specimens (up to $30 \mathrm{~cm}$ ) with cells measuring from $8 \mu \mathrm{m}$ to $12 \mu \mathrm{m}$ in length (Bourrelly, 1957; Rodriguez \& Vergon, 1996; Wehr \& Sheath, 2003).

\section{ACKNOWLEDGEMENTS}

This work was supported by the Junta de Comunidades de Castilla-La Mancha, Consejería de Educación y Ciencia, through two regional research projects (PO1109-0190-8090 1349 and PPII10-0271-1349).

\section{REFERENCES}

Aboal, M. 1988a. Zygnemataceae (Conjugales, Chlorophyceae) of the river Segura basin, southeastern Spain. Nova Hedwigia 47(3-4): 389-402.

Aboal, M. 1988b. Aportación al conocimiento de las algas epicontinentales del sudeste de España. III: Cianofíceas (Cyanophyceae Schaffner 1909). Anales del Jardín Botánico de Madrid 45(1): 1-46. 
Aboal, M. 1988c. Aportación al conocimiento de las algas epicontinentales del S.E. de España. VII. Clorofíceas (Chlorophyceae Wille in Warming 1884). Candollea 43: 521-548.

Aboal, M. 1989a. Contribución al conocimiento de las algas epicontinentales del SE de España II: Los rodófitos (Rhodophyceae). Lazaroa 11: 115-122.

Aboal, M. 1989b. Aportación al conocimiento de las algas epicontinentales del S.E. de España. V. Xantofíceas (Xanthophyceae P. Allorge ex Fritsch, 1935). Boletim da Sociedade Broteriana 62: 239-248.

Aboal, M. 1989c. Epilithic algal communities from River Segura Basin, Southeasetrn Spain. Archiv für Hydrobiologie 116(1): 113-124.

Aboal, M. (1991). Aportación al conocimiento de las algas epicontinentales del S.E. de España. VIII: Desmidiáceas y Mesoteniáceas (DESMIDIACEAE, MESOTAENIACEAE, ZYGOPHYCEAE Widder 1960). Acta Botanica Malacitana 16(2): 325-337

Aboal, M. \& Llimona, X. 1985. Aportación al conocimiento de las algas del SE de España. I. Caráceas (Characeae). Anales de Biología 6: 7-17.

Aboal, M., Puig, M.A., Sánchez-Godínez, A. \& Soler, G. 1994. Algal standing-crop in some Mediterranean temporary rivers in southeastern Spain Verhandlungen der Internationalen Vereinigung für Theoretische und Angewandte Limnologie 25: 1746-1750.

Aboal, M., López-Jiménez, E. \& Asencio, A.D. 1995. Batrachospermum atrum (Huds.) Harv. (Batrachospermales, Rhodophyceae), novedad para la flora algal epicontinental española. Anales del Jardín Botánico de Madrid 53(1): 121-123.

Aboal, M. 1996. Comunidades fitobentónicas del Parque Nacional de Las Tablas de Daimiel. In: Álvarez, M. \& Cirujano, S. (eds.), Las Tablas de Daimiel. Ecología acuática y sociedad: 117-128. Madrid.

Aboal, M., Marín, J.P. \& Nieva, A. 2006. Tetrasporidium javanicum Möbius (Tetrasporales, Chlorophyta) ¿especie invasora? Resúmenes reunión científica de la Sociedad Española de Ficología. Algas (Boletín de la Sociedad Española de Ficología) 37: 4.

Álvarez-Cobelas, M., Cirujano, S., Montero, E., Rojo, C., Rodrigo, M.A., Piña, E., Rodríguez, J.C., Soriano, O., Aboal, M., Marín, J.P. \& Araujo, R. 2007. Ecología acuática y sociedad de las Lagunas de Ruidera. C.S.I.C. Ministerio de Educación y Ciencia. Madrid.

Álvarez-Cobelas, M., Rojo,C. \& Angeler, D.G. 2005. Mediterranean limnology: current status, gaps and the future. Journal of Limnology 64(2): 13-29.

Anagnostidis, K. \& Komarek, J. 1990. Modern approach to the classification system of Cyanophytes. 5. Stigonematales. Algological Studies 59: 1-73.

APHA. 1998. Standard methods for the examination of water and wastewater. 20th Edition. American Public Health Association, American Water Works Association and Water Environment Association. Baltimore

Aziz, A. 2008. Algal flora of Madhabkunda waterfall area in Maulvi Bazar, Bangladesh. III. New records of blue-greens and greens. Bangladesh Journal of Botany 37(1): 43-48

Bellinger, E.G. \& Sigee, D.C. 2010. Freshwater algae: identification and use as bioindicators. Wiley-Blackwell. Chichester, West Sussex.

Berzas, J.J., García, L.F., Martín-Álvarez, P.J. \& Rodríguez, R.C. 2004. Quality assessment and chemometric evaluation of a fluvio-lacustrine system Ruidera Pools Natural Park (Spain). Water, Air and Soil Pollution 155: 269-289

Bornet, E. \& Flahault, C. (1886-1888): Révision des Nostocacées heterocystées contenues dans les principaux herbiers de France. Annales des Sciences Naturelles, Botanique 7, Ser. 3: 323-381.

Bourrelly, P. 1957. Recherches sur les Chrysophycées: morphologie, phylogénie, systématique. Muséum national d'histoire naturelle, Laboratoire de cryptogamie. Paris.

Bourrelly, P. 1990. Les algues d'eau douce. Initiation à la systématique. Tome I: Les algues vertes. Société Nouvelle des Éditions Boubée. Paris.

Branco, L.H.Z., Necchi Jr., O., \& Branco, C.C.Z. 2001. Ecological distribution of Cyanophyceae in lotic ecosystems of São Paulo State. Revista Brasileira de Botânica 24(1): 99-108

Cáceres, E.J. (1973): Contribución al conocimiento de las cianófitas. I. Dos novedades para la Argentina: Nostochopsis lobatus (Nostochopsidaceae) y Rivularia rufescens (Rivulariaceae). Kutzingiana, 7: 165-179.

Calado, A.J. \& Rino, J. A. 1992. Observations and taxonomic considerations on a Tetrasporidium (Chlorophyta, Tetrasporales) found in Portugal. Cryptogamie, Algologie 13(3): 157-167.

Cantonati, M., Gerecke, R. \& Bertuzzi, E. 2006. Springs of the Alps - Sensitive ecosystems to environmental change: from biodiversity assessments to long-term studies. Hydrobiologia 562(1): 59-96.
Carter, N. 1924. A monograph of the British Desmiciacea. Volume V. Ray Society. London.

Cirujano S. \& L. Medina. 2002. Plantas acuáticas de las lagunas y humedales de Castilla-La Mancha. Real Jardín Botánico (CSIC) y Junta de Comunidades de Castilla-La Mancha. Madrid.

Couté, A. \& Tracanna, B. 1981. Sur la présence en France de Tetrasporidium javanicum Möbius (Chlorophyta, Euchlorophyceae, Tetrasporales) et sa position systematique. Cryptogamie, Algologie 2(3): 209-219.

Del Grosso, F. 1977. Nostochopsis Lobatus Wood: prima segnalazione per l'Italia. Informatore Botanico Italiano 9: 285-286.

Desikachary, T.V. 1959: Cyanophyta. Monographs on Algae. Indian Council of Agricultural Research. New Delhi.

El Saied, H.E. 2007. Molecular genetic monitoring of bacterial communities in Manzala Lake, Egypt, based on 16S rRNA gene analysis. Egyptian Journal of Aquatic Research 33(3):179-194.

Eloranta, P. 2011. Süsswasserflora von Mitteleuropa, 7. Rhodophyta and Phaeophyceae. Spektrum Akademischer Verlag. Heidelberg.

Eloranta, P. \& Kwandrans, J. 1996. Distribution and ecology of freshwater red algae (Rhodophyta) in some central Finnish rivers. Nordic Journal of Botany 16(1): 107-117.

Eloranta, P. \& Kwandrans, J. 2002. Notes on some interesting freshwater Rhodophyta from Finland. Archiv für Hydrobiologie. Algological studies 143: 95-109.

Eloranta, P. \& Kwandrans, J. 2007. Freshwater red algae (Rhodophyta): identification guide to European taxa, particularly to those in Finland. Botanical Museum Finnish Museum of Natural History. Helsinki.

Entwisle, T.J. \& Skinner, S. 2001. Non-marine algae of Australia: 4. Floristic survey of some colonial green macroalgae (Chlorophyta). Telopea 9(3): 725-739.

Ettl, H. \& Gartner, G. 2009. Süsswasserflora von Mitteleuropa 10. Chlorophyta. - 2. Tetrasporales, Chlorococcales, Gloeodendrales. Spektrum Akademischer Verlag. Heidelberg.

Fott, B., Nováková, M. \& Kalina, T. 1965. Morphology, reproduction and occurrence of a tropical alga, Tetrasporidium javanicum Möbius (Chlorophyceae). Preslia 37: 380-386.

Frémy, P. \& Feldmann, J. 1934. A propos de la présence en France du Nostochopsis lobatus Wood. Bulletin de la Société Botanique de France 81(7/8): 612-618.

Gayral, P. 1951. Une rare Rhodophycee d'eau douce dans le lac d'Iseli (Haut. Atlas Central): "Chroothece rupestris" Hangs. Bulletin de la Société des Sciences Naturelles du Maroc 31: 15-18.

Geitler, L. (1930-1932): Cyanophyceae von Europa. In: L. Rabenhorst (ed.), Kryptogamen-Flora von Deutschland, Österreich und der Schweiz.: 11196. Koeltz Scientific Books. Leipzig.

González, A. \& Vázquez, A. 2000. Las formas del relieve: 1lanuras, páramos y montañas. In: Guía de Castilla-La Mancha: 17-40. Junta de Comunidades de Castilla-La Mancha. Toledo.

Hansgirg, A. 1886. Algarum aquae dulcis species novae. Oesterrichische Botanische Zeitschrift 4: 109-111.

Hieber, M., Robinson, C.T., Rushforth, S.R. \& Uehlinger, U. 2001. Algal communities associated with different alpine stream types. Artic, Antartic and Alpine Research 33(4): 447-456.

Hoffmann, L. 1990. Presence of Mastigocladopsis jogensis (Cyanophyceae, Mastigocladopsiceae) in Corsica (France). Cryptogamie, Algologie 11(2): 219-224.

Hu, H. \& Wei, Y. 2006. The freshwater algae of China. Systematics, taxonomy and ecology. Science Press. Pekin.

Israelson, G. 1942. The freshwater florideae of Sweden:studies on their taxonomy, ecology, and distribution. A.-B. Lundequistska Bokhandeln. Uppsala.

Israelson, G. 1949. Two freshwater Protofloridae new to Sweden. Botaniska Notiser: $366-376$

I.T.G.E., 2000. Unidades hidrogeológicas de España. Mapa y datos básicos. Instituto Tecnológico y Geominero de España, Madrid.

Iyengar, M.O.P. 1932. Two Little-known Genera of Green Algae (Tetrasporidium and Ecballocystis). Annals of Botany 46(2): 191-192.

Komárek, J., King, H. \& Komárková, J. 2003: Filamentous Cyanobacteria. In: Wehr, J.D. \&. Sheath, R (eds.), Freshwater algae of North America. Ecology and Classification: 117-196. San Diego.

Kouwets, F.A.C., 1999. A check-list of desmids (Chlorophyta, Zygnemaphycea) of France. Muséum national d'histoire naturelle. Paris.

Krizmanic, J., Subakov-Simic, G. \& Karadzic, V. 2008. Supplementary notes 
on the distribution of Hydrurus foetidus (Vill.) Trevisan (chrysophyta) in Serbia. Archives of Biological Sciences 60(2): 13-14.

Kumano, S. 2002. Freshwater red algae of the world. Biopress. Bristol. 375 pp. Llimona, X., Ballesteros, E., Brugués, M., Comín, F.A., Cros, R.M., Molero, J., Romero, J., Tomás, X. \& Torrella, F. 1985. Història natural dels països catalans. 4, Plantes inferiors. Enciclopèdia Catalana. Barcelona.

López-Rodríguez, M.C. \& Penalta-Rodríguez, M. 2007. Freshwater algae in Galician Central Macizo rivers (NW Spain) with new records for the Iberian Peninsula. Algological Studies 125: 57-77.

Margalef, R. 1948. Flora, fauna y comunidades bióticas del Pirineo de la Cerdaña. Monografías de la Estación de Estudios Pirenaicos Vol, 11. C.S.I.C. Zaragoza.

Margalef, R. 1950. Datos para la hidrobiología de la cordillera cantábrica, especialmente del macizo de los Picos de Europa. Publicaciones del Instituto de Biología aplicada 7: 37-76.

Margalef, R. 1955. Materiales para una flora de las algas del NE de España. VI. Desmidiales, Rhodophyceae. Collectanea Botanica 4(3): 319-330.

Margalef, R. 1983. Limnología. Ediciones Omega, Barcelona.

Marín-Murcia, J.P. \& Aboal, M. 2007. Estudio de las comunidades vegetales de los canales de Montijo y Lobón y de las condiciones que favorecen su desarrollo (informe técnico). Confederación Hidrográfica del Guadiana. Ministerio de Medio Ambiente.

Moreno, J.L., Ros, M.R. \& De las Heras, J. 2011. La flora acuática de los ríos y humedales de Castilla-La Mancha: Comunidades, hábitats y medidas de conservación. In: Hernández, J.E. \& Herranz, J.M. (eds.), Protección de la diversidad vegetal y de los recursos fitogenéticos de Castilla-La Mancha: 277-315. Albacete.

Moreno, J.L., Aboal, M. \& Monteagudo, L. 2013. On the presence of Nostochopsis lobata Wood ex Bornet et Flahault in Spain: morphological, ecological and biogeographical aspects. Nova Hedwigia 95: 373-390.

Nägeli, C., 1849. Gattungen einzelliger Algen: physiologisch und systematisch bearbeitet. Friedrich Schulthess. Zurich.

Neag, I., Momeu, L., Peterfi, L.S. 2005. Algal communities from some aquatic habitats of the "Alexandru Borza" Botanical Garden, Cluj-Napoca, Romania. Contribu ii Botanice 40: 153-162.

Palmer, C.M. 1941. Additional records for algae, including some of the less common forms. Butler University Botanical Studies 5(1): 224-234.

Pandey, U. \& Pandey, J. 2008. Enhanced production of biomass, pigments and antioxidant capacity of a nutritionally important cyanobacterium Nostochopsis lobatus. Bioresource Technology, 99(10): 4520-4523.

Peerapornpisal, Y., Amornledpison, D., Rujjanawate, C., Ruangrit, K. \& Kanjanapothi, D. 2006. Two Endemic Species of Macroalgae in Nan River, Northern Thailand, as Therapeutic Agents. Science Asia 32(1): 71-76.

Pentecost, A. 1991. A new and interesting site for the Calcite-encrusted desmid Oocardium stratum Naeg. in the British Isles. British Phycological Journal 26: 297-301.

Prescott, G.W., Croasdale, H.T., Vinyard, W.C., Bicudo, C. 1981. A synopsis of North American desmids. Part II. Desmidiaceae: Placodermae. Section 3. University of Nebraska Press. Lincoln.

Rodriguez, S. \& Vergon, J.P. 1996. Guide pratique de détermination générique des algues macroscopiques d'eau douce. Ministère de l'environnement. Paris.
Rott, E., Pfister, P., van Dam, H., Pall, K., Pipp, E., Binder, N. \& Ortler, K., 1999. Indikationslisten für Aufwuchsalgen. Teil 2: Trophieindikation und autökologische Anmerkungen. Bundesministerium für Land- und Forstwirtschaft. Wien.

Sabater, S, Aboal, M. \& Cambra, J. 1989. Nuevas observaciones de rodofíceas en aguas epicontinentales del NE y SE de España. Limnetica 5: 93-100.

Sánchez-Castillo, P.M. 1984. Estudio ficológico de la vegetación reófila de Sierra Nevada (Granada). Limnetica 1: 136-140.

Sarma, P. \& Chapman, V.J. 1975. Occurrence of the genus Nostochopsis in New Zealand. Nova Hedwigia 26: 305-308.

Sheath, R.G., Vis, M.L. \& Cole, K.M. 1993. Distribution and systematics of Batrahcospermum (Batrachospermales, Rhodophyta) in North America. 3. Section Setacea. Journal of Phycology 29(5): 719-725.

Sheath, R.G. \& Sherwood, A.R. 2002. Phylum Rhodophyta (Red Algae). In: John, D.M., Whitton, B.A. \& Brook, A.J. (eds.), The freshwater algal flora of the British Isles. An identification guide to freshwater and terrestrial algae: 123-143. Cambridge.

Sherwood, A.R. 2004. New records of freshwater macroalgae and diatoms form Hawaian Islands. Bishop Museum Occasional Papers 79: 3-8.

Skinner, S. \& Entwisle, T.J. 2001. Non-marine algae of Australia: 1. Survey of colonial gelatinous blue-green macroalgae (Cyanobacteria). Telopea 9(3): 573-599.

Sladecek, V. 1973. System of water quality from the biological point of view. Archiv für Hydrobiologie, Ergebnisse der Limnologie 7: 1-218.

Starmach, K. 1977. Phaeophyta. Rhodophyta. Flora Stodkowodna Polslci, vol. 14. Polska Academia Nauk, Instytut Botaniki.Warsaw.

Tiwari, D.N. 1978. The heterocysts of the blue-green alga Nostochopsis lobatus: Effects of cultural conditions. New Phytologist 81(3): 653-656.

Tomás, P., Moreno, J.L., Aboal, M., Oscoz, J., Durán, C. \& Navarro, P. Distribución de Tetrasporidium javanicum Möbius, 1893 (Chlorophyta: Tetrasporales) en la cuenca del río Ebro. Limnetica (in press).

Van Oye, P. \& Hubert, B., 1937. Recherches sur les "crons" du jurassique belge. Données générales. Biologische Jaarboek Dodonaea 4: 231-235.

Vrhovsek, D., Kosi, G., Krivograd-Klemencic, A., Smolar-Zvanut, N., Bernik, T., Grbovic, J., Roser-Drev, A. \& Remec-Rekar, S. 2006. Monograph on freshwater and terrestrial algae in Slovenia. Zalozba ZRC, ZRC SAZU. Ljubljana.

Weber, B., Wessels, D.C.J. \& Budel, B. 1996. Biology and ecology of cryptoendolithic cyanobacteria of a sandstone outcrop in the Northern Province, South Africa. Algological Studies 83: 565-579.

Wehr, J.D. \& Sheath, R.G. 2003. Freshwater algae of North America: ecology and classification. Academic Press. Boston.

West, G.S. 1904. A Treatise on the British Freshwater Algae. Cambridge University Press. Cambridge.

Wood, H.C. 1872: A contribution to the history of the fresh-water algae of North America. Smithsonian Contributions to Knowledge, 241. Washington.

Yoneda, Y. (1939): Studies on the thermal algae of Hokkaido (1). Acta Phytotaxonomica et Geobotanica 8: 101-107.

Associate Editors: Javier Fuertes / Santos Cirujano Received: 19-VI-2012 Accepted: 7-IV-2013 